\title{
Medical Device Misplaced
}

National Cancer Institute

\section{Source}

National Cancer Institute. Medical Device Misplaced. NCI Thesaurus. Code C122713.

A medical device that was placed in an unintended location. 